\title{
FOGO DE (NO) CHÃO: PINHÃO, QUIRERA E CHIMARRÃO - A COMIDA COMO BASE CULTURAL DA REGIÃO DO CONTESTADO
}

\author{
Heitor Matos da Silveira ${ }^{1}$ \\ Nilson Cesar Fraga ${ }^{2}$
}

- Enviado em 20/09/2015

- Aprovado em 30/10/2015

\begin{abstract}
RESUMO
O presente artigo tem como escopo apontar os resultados obtidos durante a pesquisa "Fogo de (no) chão: pinhão, quirera e chimarrão - a comida como base cultural da Região do Contestado" onde discutimos o conceito de sabor na Geografia a partir das comidas típicas da referida região e do caboclo, como a quirera com porco, o pinhão sapecado e o consumo da erva-mate. A Geografia tardou em estabelecer relações com o estudo da alimentação, diferentemente do que aconteceu com a Antropologia, que tem em sua base fundante o estudo das práticas alimentares, e a História, em seus estudos sobre a história da alimentação. Apesar dessa tardia relação, os geógrafos culturais passaram a considerar a alimentação e os processos de cozimento como atos culturais, buscando compreender desde a produção até as formas de consumo, manuseio, cozimento e preparo. Com a ascensão da geografia humanista e a busca por uma geografia e uma ciência orgânica, recolocando o ser no espectro dos estudos geográficos e da ciência, se preocupando com a experiência geográfica, mediada pelos sentidos do corpo. Sabor, saber e paisagem são a tríade central deste estudo, ao passo que os saberes de preparo, cozimento e colheita dos alimentos criam paisagens específicas de cada lugar, regendo os sabores dos lugares, regiões. O pinhão, a quirera com porco e o chimarrão são a base alimentar do caboclo e criam paisagens contestadas a partir destes sabores, requerendo estudos mais aprofundados para se pensar na cultura, na identidade e no meio ambiente.
\end{abstract}

Palavras-chave: Geografia Cultural-Humanista. Sabor. Região do Contestado.

\section{POR UMA GEOGRAFIA MAIS SABOROSA}

A geografia se dedicou, ou se dedica, aos estudos sobre a comida, sua produção e sua distribuição na alimentação humana, mas tardou em tecer relações com o estudo do sabor e, seguramente, do estudo da própria dimensão cultural da alimentação, que se diferem em vias

\footnotetext{
${ }^{1}$ Graduado em Geografia pela Universidade Estadual de Londrina. Pesquisador do Laboratório de Geografia, Território, Meio Ambiente e Conflito. Endereço eletrônico: silveira.heitorm@gmail.com

${ }^{2}$ Geógrafo. Doutor em Meio Ambiente e Desenvolvimento pela UFPR. Bolsista PQ/CNPq. Professor Adjunto da UEL. Coordenador do Lab. Geografia, Território, Meio Ambiente e Conflito. Endereço eletrônico: nilsoncesarfraga@hotmail.com
} 
epistemológicas importantes. Ao se propor estudar o sabor, diferentemente da alimentação, os geógrafos se debruçam em estudar a experiência geográfica, mediada pelo corpo e pelos sentidos (olfato, paladar, visão, audição e tato), ou seja, é uma menção aos estudos relativos à percepção ambiental desenvolvidos em meados dos anos 1970 e 1980 (MARANDOLA JR., 2012). Alimentarse é, sobremaneira, um ato cultural, que transforma a comida, crua, retirada do solo em cultura, pois há uma gama de processos de preparo, tempero, forma de colheita e de consumo que são particulares a cada região, povo, local, nação (MACIEL, 2004, 2005; MINTZ, 2001).

Em seu clássico A Geografia Cultural, Paul Claval dedica um capítulo para explicitar o estudo em geografia da alimentação, e como esta temática é um caminho profícuo para os geógrafos (CLAVAL, 2002, 2007). Apesar dessa menção, poucos são os trabalhos desenvolvidos que se apoiam nessa temática, tendo sido mais amplamente produzidos, no Brasil, recentemente. A indissociabilidade entre geografia cultural e geografia humanista (a que nos reportaremos como geografia cultural humanista) (MARANDOLA JR., 2005a) conduz a discutir o sabor na geografia a partir de um aporte fenomenológico-existencialista, ou seja, pensarmos o sabor enquanto mediador da relação homem-terra, seja ela pela via cultural (numa escala coletiva, de construção de identidades), seja pela via do hedonismo (numa perspectiva do sabor enquanto saber) ou pela via do imaginário (numa escrita telúrica da terra tendo como essência a paisagem e o entrelaçamento entre terra-paisagem-homem), ligado à experiência e, também, à existência (MARANDOLA JR., 2005b).

Ao pretender um estudo dos alimentos se está, direta e indiretamente, penetrando na fronteira dos saberes que envolvem a geografia agrária e rural, a partir de uma senda geográfica humanista conduzida pelo método fenomenológico, convergindo-se para uma geografia dos sabores, que exprime uma maneira humanista, fenomenológica e cultural de se fazer e de se pensar a própria geografia agrária (HOLZER, 2014). Neste sentido, um estudo geográfico humanista da geografia agrária alerta para a necessidade latente de uma revigoração epistemológica da referida especialidade geográfica, aportando-se para os sentidos do corpo, que mediam a relação do ser cognoscente com o mundo (MARANDOLA JR., 2012; MERLEAU-PONTY, 2011).

A geografia dos sabores, previamente, é conduzida por três vias que se conformam, atualmente, nos grandes nortes para o estudo geográfico do sabor: a cultura, na conformação de identidades regionais de um grupo, uma comunidade, um povo e uma nação; do hedonismo, onde se coloca o corpo no cerne dos estudos, a partir da experiência geográfica, em que os sentidos distais, considerados classicamente como sentidos pouco importantes para o conhecimento - em decorrência de seu contato direto com o objeto e causando a apreensão do mesmo a partir da 
volição e do prazer - passem a construir também o conhecimento geográfico; e imaginário, numa escrita telúrica e imaginária das essências geográficas, paisagem e lugar. Estas três vias confluem para a geograficidade, dimensão ontológica da geografia, que expressa a condição de ser-no-mundo da relação visceral do homem com a terra (DARDEL, 2011).

No artigo em tela, buscamos desvelar os saberes e o sabores da Região do Contestado, partindo de três pratos que são marcas da culinária e da alimentação cabocla: a quirera com porco, o pinhão sapecado e a erva-mate. Os três advêm e são elementos predominantes na paisagem, como as araucárias, o milho, os porcos criados soltos, e os ervais que concedem a folha da erva-mate. É possível observar a relação intrínseca, e que procuramos defender em nossas discussões, entre sabor, saber e paisagem. Saboreamos a paisagem e a incorporamos através dos alimentos, onde cultura, hedonismo e imaginário se fundem numa procura por uma ciência e geografia orgânica e mais humanista.

Para o desenvolvimento da pesquisa, foram feitos levantamentos bibliográficos, para a construção do marco teórico que norteou a temática do projeto, tais como a Geografia Cultural, Alimentação e Cultura, Geografia Humanista e Geografia dos Sabores. Após o levantamento bibliográfico, foram feitos três trabalhos de campo para a Região do Contestado, nos municípios catarinenses de Timbó Grande, Canoinhas e Calmon. Os trabalhos de campo permitiram desvelar saberes e sabores do Contestado, como os processos de preparo da quirera com porco, a sapecada do pinhão na mata de Araucária e os ervais presentes na região. Após o trabalho de campo, foram redigidos diários de campo que foram sistematizados e expostos no decorrer do relatório.

Sabor, saber e paisagem são dimensões indissociáveis ao se pretender um estudo geográfico humanista e fenomenológico da Geografia Agrária, como propôs Holzer (2014). Os saberes regem sabores que advém da paisagem, onde ingerimos a paisagem e os processos de cozimento compõem paisagens culturais específicas de cada região e de cada povo, demarcando-o culturalmente. O hedonismo é presente, no prazer e na volição, dimensões que foram separadas e negligenciadas no desenvolvimento do pensamento científico moderno, e que devem ser resgatadas para se pensar e se requerer uma ciência geográfica humanista e fenomenológica. A percepção é um traço seminal do conhecimento, e toma-lo apenas pelo seu traçado visual limita-o e tira os demais sentidos corpóreos dos esquemas de produção do conhecimento.

O estudo geográfico do sabor, ou Geografia do Sabor tal qual vem sendo construída, deve englobar a paisagem. Seja a paisagem enquanto marca e matriz, seja a paisagem como uma experiência do sentir e a inserção do ser-no-mundo, sabor e paisagem são essências importantes e 
indissociáveis na Geografia dos Sabores. O caminho dessa geografia, enquanto pensamento fenomenológico da/na geografia agrária, está ainda em construção, sendo que tais caminhos tendem a serem ampliados, e novas perspectivas de estudo surgirem no seio da geografia, tendo como esteio o humanismo e a fenomenologia, buscando a experiência geográfica em sua inteireza.

\section{SABORES E SABERES DO CONTESTADO}

Nesta seção do artigo, nos ocuparemos em relatar os trabalhos de campo realizados para a Região do Contestado (SC/PR), conforme a figura 1. Nossa acepção de paisagem é oriunda de Augustin Berque, que aponta dois movimentos da paisagem: da paisagem enquanto marca e a paisagem enquanto matriz. A região situa-se no extenso domínio das Araucárias, que possui como elemento marcante a Araucaria angustifolia.

$\mathrm{O}$ arguto geógrafo Aziz Ab’Saber permite um entendimento profícuo do surgimento desse extenso domínio da natureza. Para o geógrafo, esse domínio se origina em decorrência da perda de tropicalidade ao se adentrar nessa porção do território brasileiro, sendo uma "condicionante climática que tornou possível a ampla e contínua instalação de um domínio de natureza extratropical, constituído por araucárias emergentes acima do dossel de matinhas subtropicais" (AB'SABER, 2003, p.101). A descrição da paisagem, em conjunto com as análises geomorfológicas e geológicas de Ab’Saber (2003) permite-nos compreender a distribuição espacial desse domínio, que se vinculam aos planaltos da "vasta hinterlândia do Paraná, Santa Catarina e Rio Grande do Sul, onde predominam climas temperados úmidos, de altitude" (AB'SABER, 2003, p.102). 
Figura 1 - Localização da Região do Contestado (SC/PR).
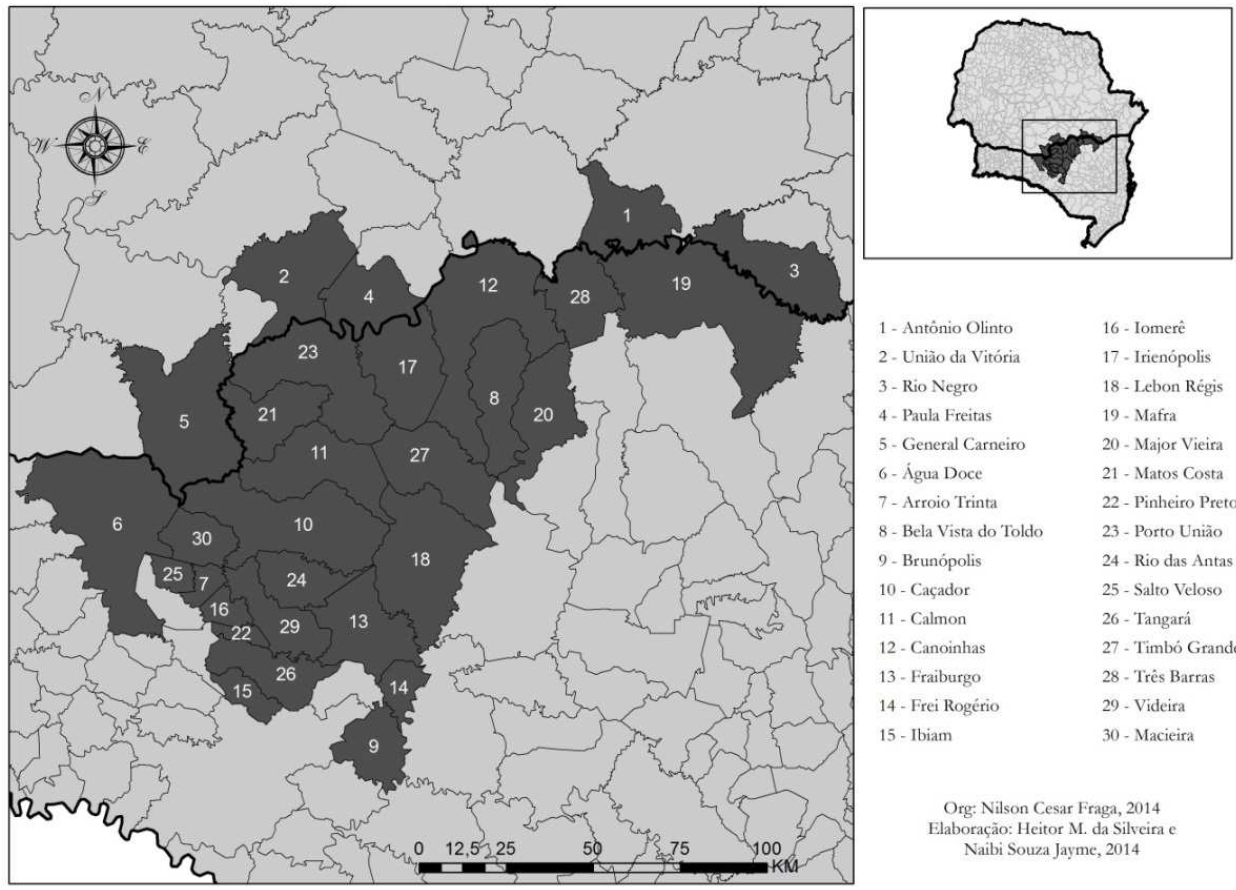

Fonte: Silveira e Jayme (2014).

A araucária representa um elemento importante na vida do caboclo da região. $\mathrm{Na}$ realidade, ela sempre se fez importante, desde os indígenas da região, os Xocrén (Xokleng) e os Kaingang, que tinham nela uma fonte de alimento abundante nos períodos mais gélidos do planalto catarinense e paranaense (QUEIROZ, 1981). Atualmente é uma tarefa árdua encontrar uma área relativamente extensa que possua uma concentração importante de araucárias; podemos encontra-la em apenas alguns pontos de ambos os estados, recortadas pelas rodovias que fazem a ligação interestadual e intrarregional.

O primeiro trabalho de campo ocorreu no município de Canoinhas - SC, mais precisamente no Faxinal Grein, uma área de um relativo difícil acesso mas composta por uma paisagem regida por araucárias e ervais. No conjunto dessa paisagem, alguns produtores criavam porcos soltos, que se alimentavam do pinhão e da erva-mate para engordar, diferentemente do porco atualmente consumido que advém de confinamentos e é alimentado com lavagem ou ração, o que modifica substancialmente o sabor da carne e o teor da comida. Ficamos hospedados em Timbó Grande - SC e, junto de Jucelei Souza, Naibi Jayme e Anderson Souza fomos até o Faxinal Grein. Ao adentrarmos na propriedade do senhor R. G., fomos prontamente guiados para o local onde os porcos estavam confinados, conforme a figura 2, sendo estes alimentados, também, pelo milho triturado em granulação específica para o preparo da quirera, ou seja, o próprio milho que alimenta 
a população num dos pratos mais típicos da região é, também, fonte fundamental para engorda dos porcos que compõem a quirera com porco.

Figura 2 - Local onde os porcos estavam confinados, na propriedade do senhor R. G.

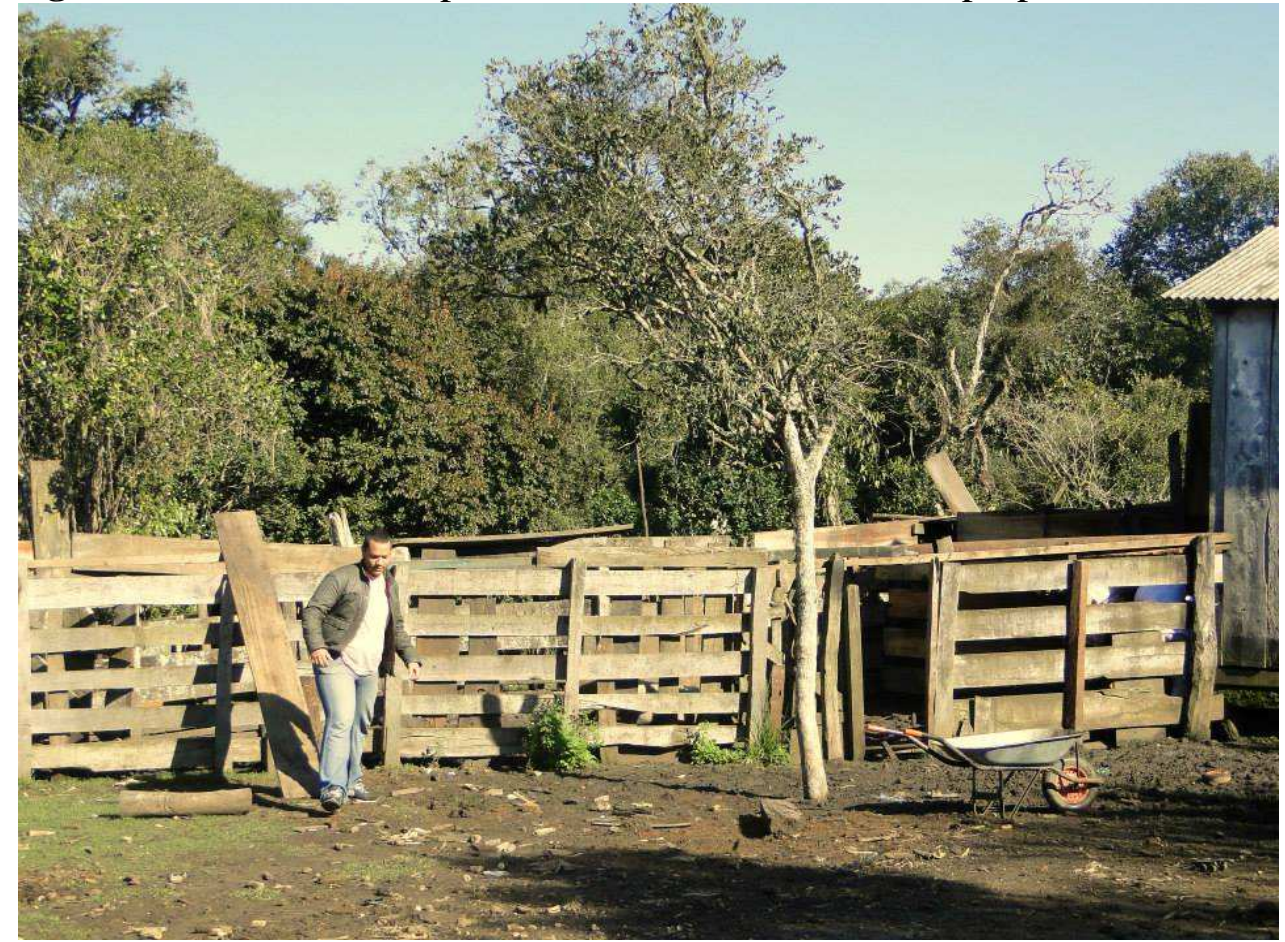

Fonte: os autores, 2015.

Acompanhamos o processo de abate e limpeza do porco. O porco é abatido com um porrete na cabeça e, depois, tem seu coração perfurado por uma faca. Essa é um dos processos mais comuns e importantes para se abater o porco. Com o porco abatido, ele é colocado em um suporte de madeira, com certa inclinação para que o sangue e demais resíduos do corpo possam escorrer e não contaminar a carne. Em um braseiro, a água quente é retirada do tacho e despejada por cima do porco, para que o processo de retirada do pelo seja mais fácil, sem danificar a carne e o couro; com uma faca, raspam-se os pelos do porco até que este fique completamente limpo, conforme a figura 3. Após a retirada dos pelos, as patas são cortadas e jogadas fora, apesar de ser uma parte nobre do porco. O porco é aberto da altura do pescoço até a região sacal, e a barrigada é aberta de forma relativamente delicada para não perfurar o intestino e/ou estômago e contaminar a carne com resíduos de fezes ou sucos gástricos. 


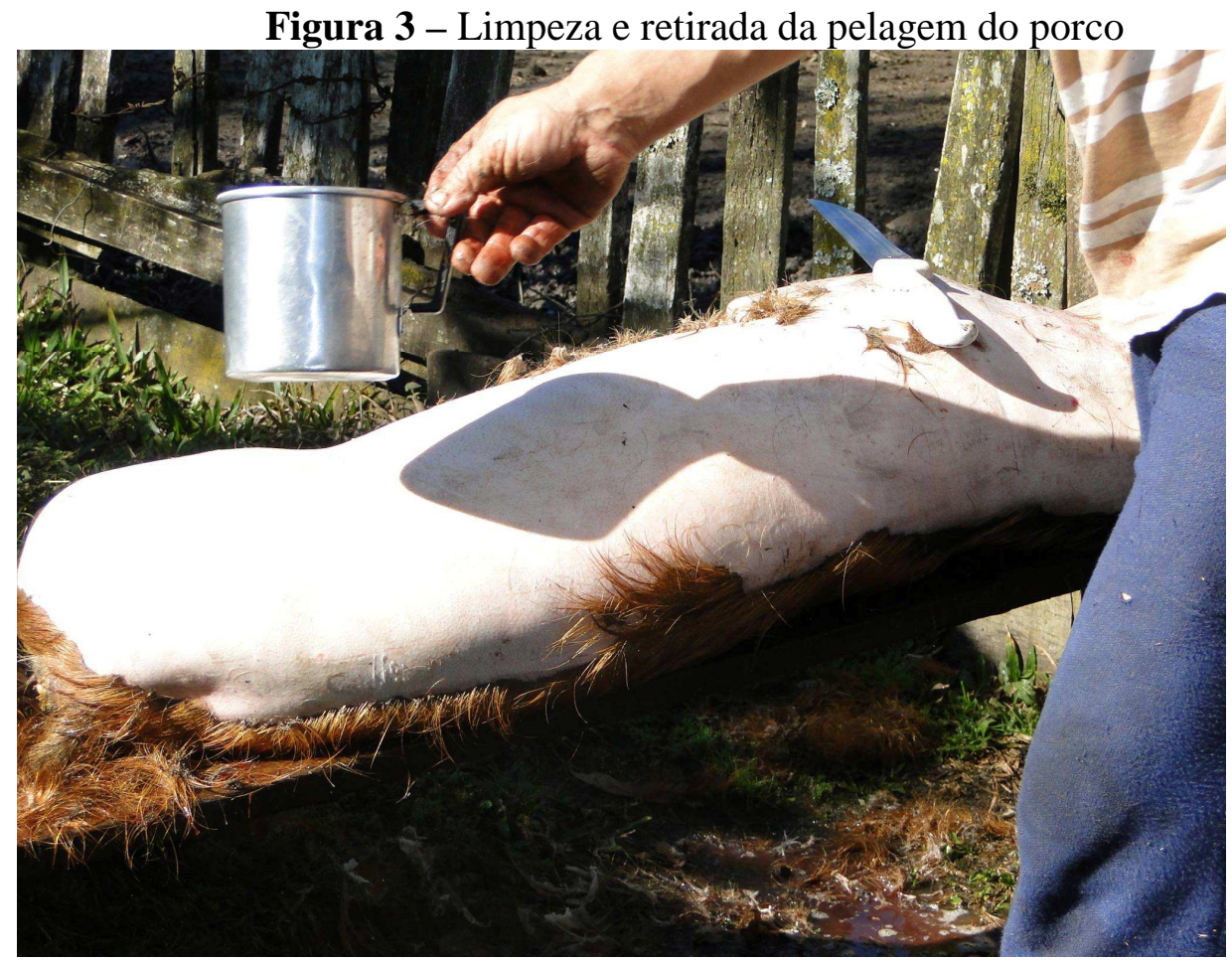

Fonte: os autores, 2015

Após a limpeza interna do porco, este é pesado e colocado para secar e, após isso, é cortado, retirando-se as partes mais importantes do porco, como a cabeça, o pernil, a panceta e as costelas. Tanto a panceta, como a costela e partes do pernil servirão de base para o preparo da quirera. A quirera é produzida a partir do milho, base da alimentação cabocla, sendo moída até atingir uma granulação especifica sem ficar da espessura da farinha de fubá ou tão grossa como próxima da granulação dos flocos de milho.

Por ser um grão moído, ela é primeiro hidratada e, depois, em uma panela com demais condimentos, é acrescentada a quirera hidratada e esquentada no fogão a lenha. Em uma outra panela, a carne de porco é frita com a própria banha do porco e, que com a própria gordura da panceta, lhe confere um sabor específico, conforme a figura 4 abaixo que representa tanto a quirera sendo preparada como a carne de porco.

Farinha de milho com feijão, quirera com um naco de carne, quando há, eis aí os pratos de todo dia. Se escasseia a comida, o mate-chimarrão, tomado habitualmente desde manhã cedinho, conforta o estômago. [...]. Vez por outra, aparece às refeições [...] alguma caça e principalmente pinhão. O pinheiral é o paiol dos pobres. Pena que só frutifique nos meses mais frios, e que após levar três anos produzindo que é um desperdício, passe um tempo imprevisível sem dar fruto quase nenhum (QUEIROZ, 1981, p. 37). 
Figura 4 - Preparo da quirera e da carne de porco em fogão a lenha

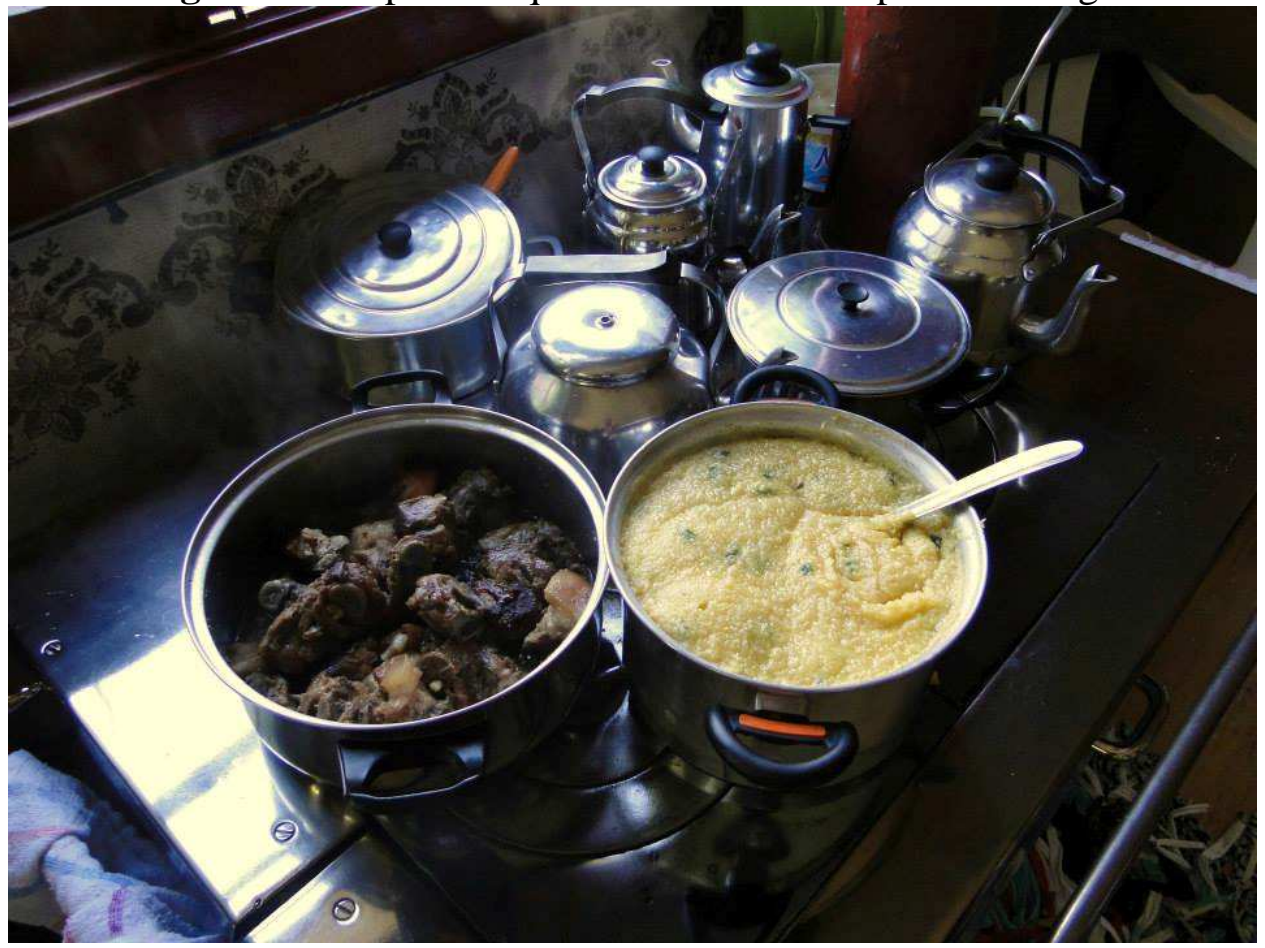

Fonte: os autores, 2015

No entremeio do processo de preparo da quirera e durante o saborear da paisagem, o chimarrão se faz presente e compõe a relação sabor e paisagem, enquanto traços culturais, como apontaria Holzer (2014). Como denotado anteriormente, a paisagem é marcada, desde as araucárias e os porcos criados soltos, por ervais. A erva-mate é um produto extremamente importante para a região sul brasileira, tanto em termos econômicos, que marcou profundamente os ciclos econômicos do Paraná e de Santa Catarina, como por exemplo indica Carlos Roberto Antunes dos Santos, ao tratar da história da alimentação no Paraná, onde a erva-mate tem papel seminal tanto na alimentação como na economia onde, em tempos de crise, impactava, também, a economia internacional (SANTOS, 1995) como por expressar toda uma cultura gaúcha, catarinense e paranaense de preparo e degustação do chimarrão.

Maurício Vinhas de Queiroz descreve o processo de extração e preparo da erva-mate. A colheita é geralmente realizada em maio a agosto, sendo que cada planta pode ser cortadas de três em três anos. O corte é realizado com facão ou foice, sendo sucedido dos processos de sapeco, secagem, quebramento, peneiração e ensaque. O sapeco é semelhante ao sapeco do pinhão, diferenciando-se pelo fato de não ser realizado na grimpa mas, sim, em uma simples fogueira, causando uma simples tostagem das folhas (QUEIROZ, 1981). 
Após o sapeco, realiza-se a secagem, em carijós ou barbaquás, representando técnicas rudimentares de processamento da erva, consistindo em estrados de madeiras e de varas de cipó, onde os feixes de erva mate são colocados. Abaixo da armação, acende-se uma fogueira baixa, de modo que as folhas não peguem fogo ou acabem sapecando mais, sendo que o procedimento acaba quando o braseiro chega ao fim. O procedimento seguinte ao de secagem é o de quebramento, realizado na cancha, um recipiente circular. $\mathrm{O}$ processo rudimentar consiste em malhar os ramos com facões de pau para separar as folhas e transformá-las em pó; o processo mais elaborado consiste em rolos cilíndricos e cônicos, presos em eixos que são arrastados em círculos por burros e cavalos. Esse pó obtido é peneirado e o produto ensacado em bolsas de taquara revestidas de folhas de taquara, sendo transportado no lombo da mula (QUEIROZ, 1981).

Figura 5 - Erva-mate no Faxinal Grein

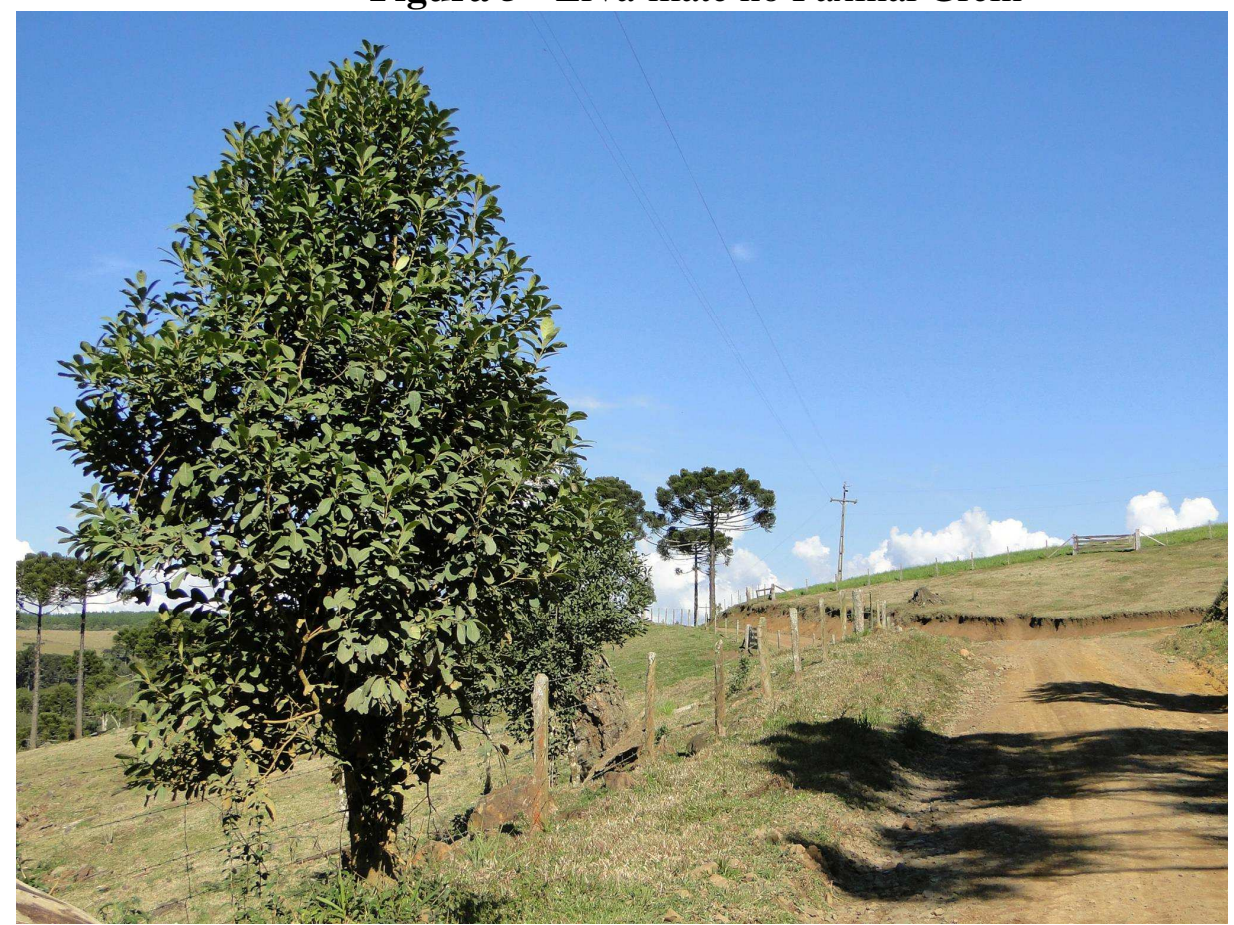

Fonte: os autores, 2015

O segundo trabalho de campo foi realizado na comunidade de Cachoeira, localizado no município de Timbó Grande - SC, na companhia de Naibi Souza Jayme Edna Pereira da Silva, realizado em maio de 2015. O trabalho de campo consistia em analisar e participar da Feira Cabocla que ocorreria na comunidade de Cachoeira, em que haveria um almoço caboclo, seguido de uma missa cabocla. Nisso, o fundamental seria buscar compreender os processos de preparo de dois 
típicos pratos caboclos: a quirera com porco e a couve refogada, porém, para a pesquisa, a quirera com porco é de maior interesse.

Ao chegarmos na Feira Cabocla, os preparativos já estavam sendo feitos, e a quirera já estava sendo preparada. O mesmo procedimento de preparo da quirera observado no primeiro trabalho de campo foi possível de ser observado nesse: a quirera é primeiramente hidratada e colocada em uma panela com demais temperos e a carne de porco é frita separadamente com banha de porco, que pode ser observado na figura 6.

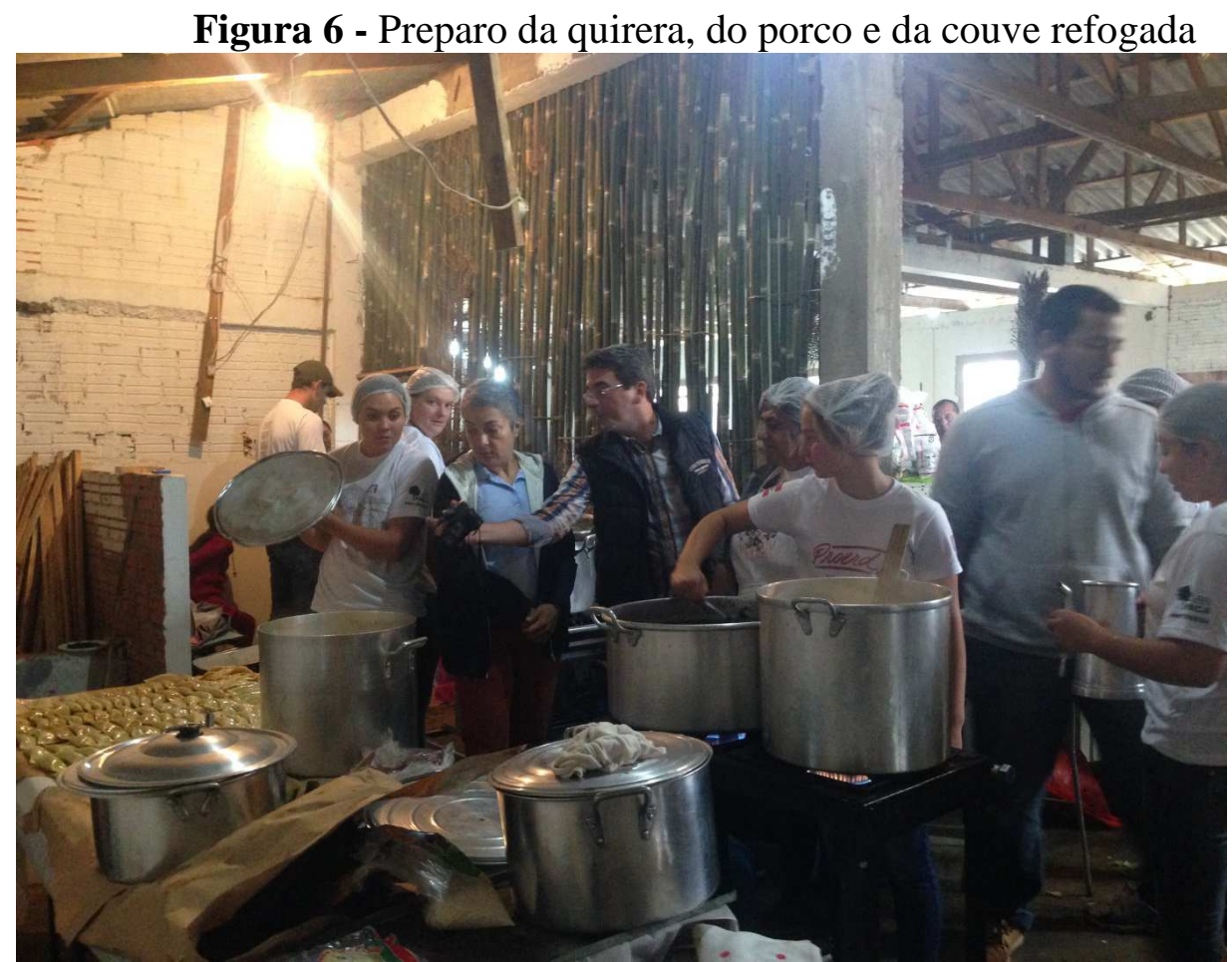

Fonte: os autores, 2015

Caminhamos junto com Edna e Naibi até a parte de trás do estabelecimento em que ocorreria a Missa Cabocla e seria servida a comida, onde encontramos um grupo de homens que estavam fazendo o preparo da carne de porco. As carnes estavam dispostas em dois tachos: um tacho com a carne de porco criado em confinamento e o outro tacho com a carne de porco em que era criado solto, se alimentando de pinhão e milho. Ao nos aproximarmos do local, fomos recebidos por Barba (figura 7), um conhecido morador da região. Barba veio há muitos anos para Timbó Grande e possui uma fazenda na região, cuja casa foi construída por ele com a madeira que há disponível no local. Ao perguntarmos da diferença das carnes, Barba comenta que as duas carnes são relativamente diferentes, onde a carne do porco criada solta é mais saborosa que a do porco 
criado em confinamento. É importante essa diferenciação, pois, os pratos típicos cozinhados pelos caboclos eram abastecidos pelo porco criado por eles soltos, que se alimentavam do pinhão e do milho.

Há uma diferença substancial entre os sabores das carnes e da própria coloração: a carne de porco criado solto possui um sabor mais tenro e suave, não forte e robusto como a carne do porco criado em confinamento, bem como uma cor mais viva. A alimentação do porco a partir da própria paisagem é fundamental para o sabor.

Figura 7 - Diálogo com Barba enquanto as carnes de porco são preparadas nos tachos

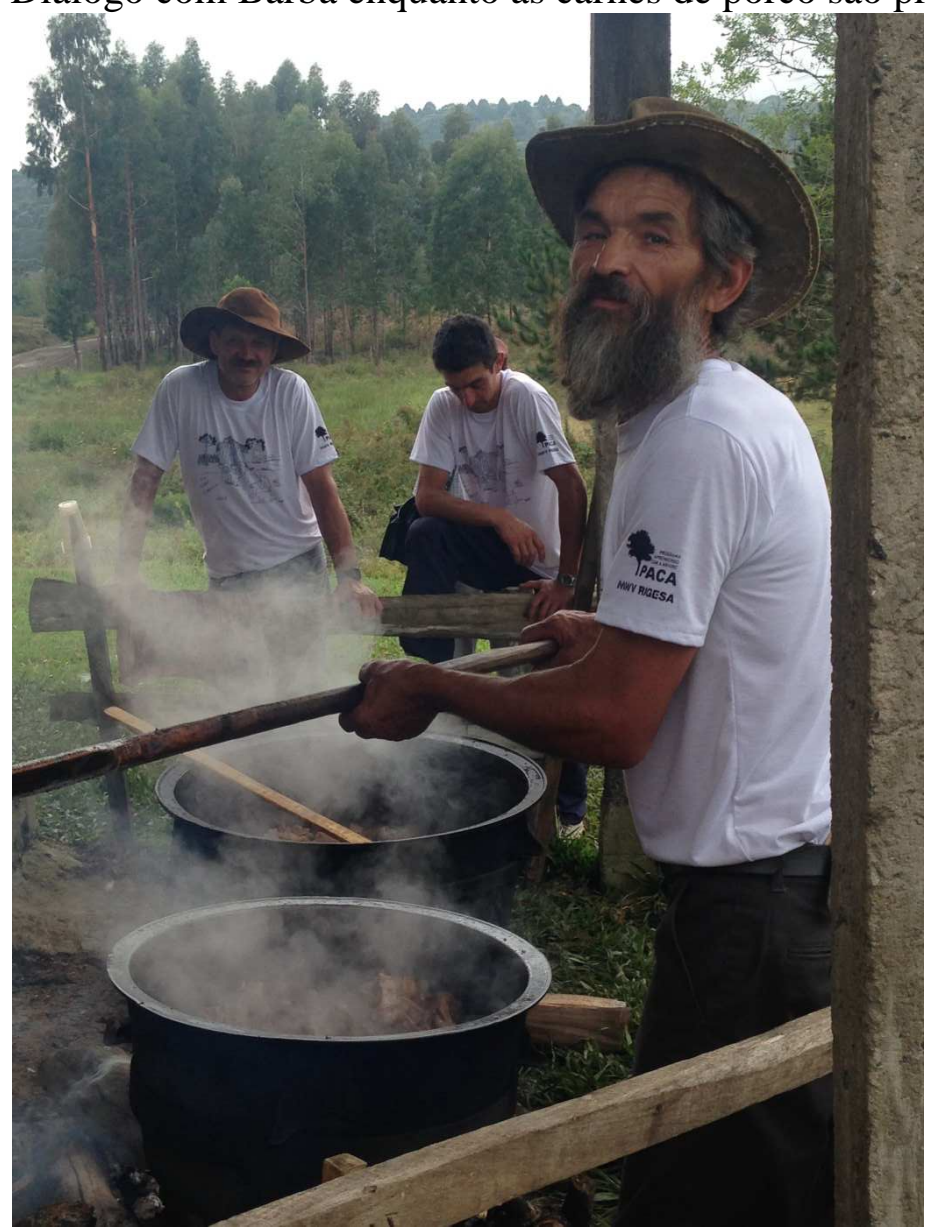

Fonte: os autores, 2015

A carne é colocada no tacho que está alojado acima de uma fogueira de madeira; as partes selecionadas já se apresentam gordurosas, ao passo que durante o processo de cozimento a gordura da carne auxilia na fritura da mesma, conforme as figuras 7 e 8 abaixo. 
Figura 8 - Preparo da carne de porco no tacho

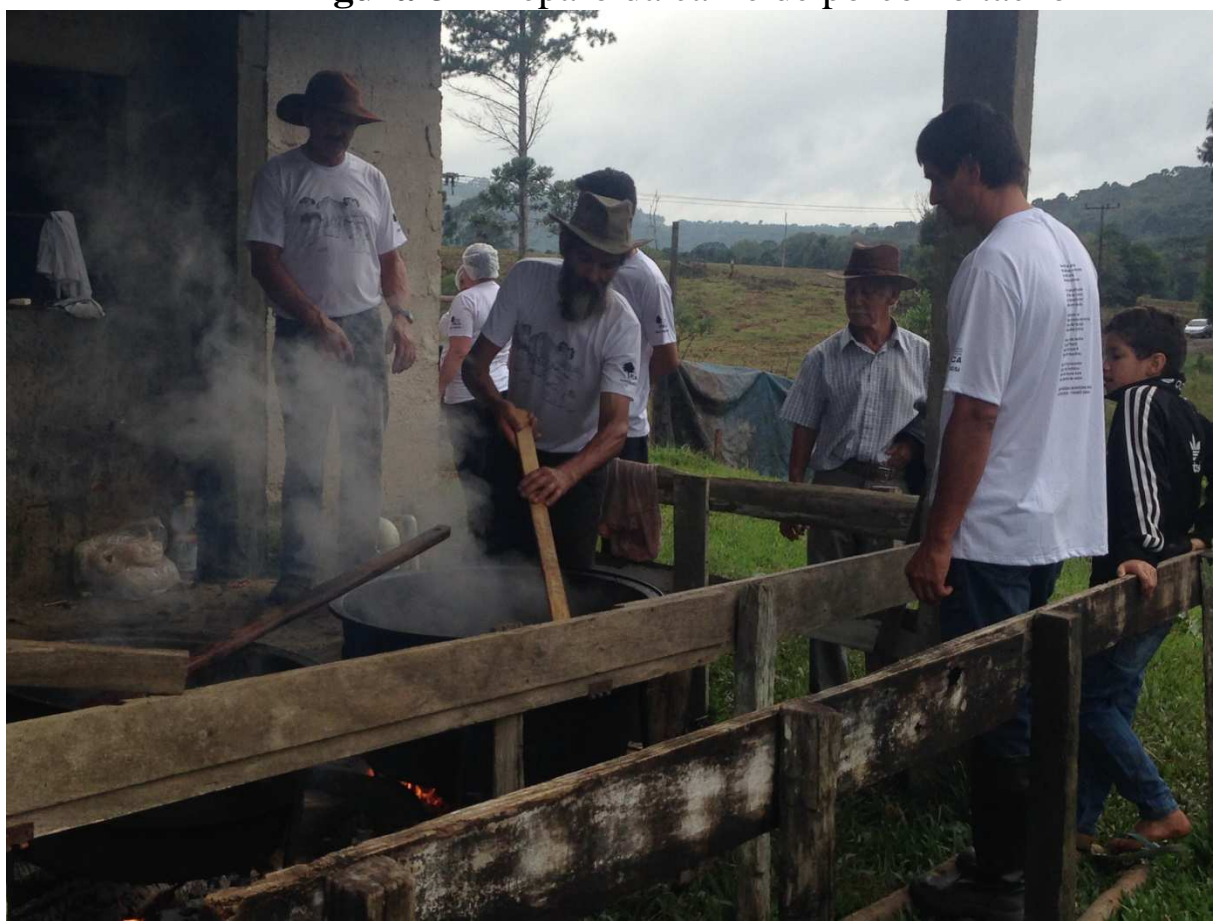

Fonte: os autores, 2015

Há duas formas de se servir a quirera com porco: uma, vista durante o trabalho de campo, onde a carne de porco é incorporada na quirera e a outra são ambos separados, sendo a quirera preparada unicamente com a água e os demais temperos e a carne de porco frita nos tachos, conforme a figura 9, que demonstra a forma de se servir a quirera e a carne de porco preparada durante a Feira Cabocla. A quirera com porco geralmente é servida com feijão preto e couve refogada na banha de porco, que compõe um prato tipicamente caboclo e uma marca cultural alimentar dos caboclos e da Região do Contestado. 
Figura 9 - Prato tipicamente caboclo, com a quirera, o porco no tacho e a couve refogada

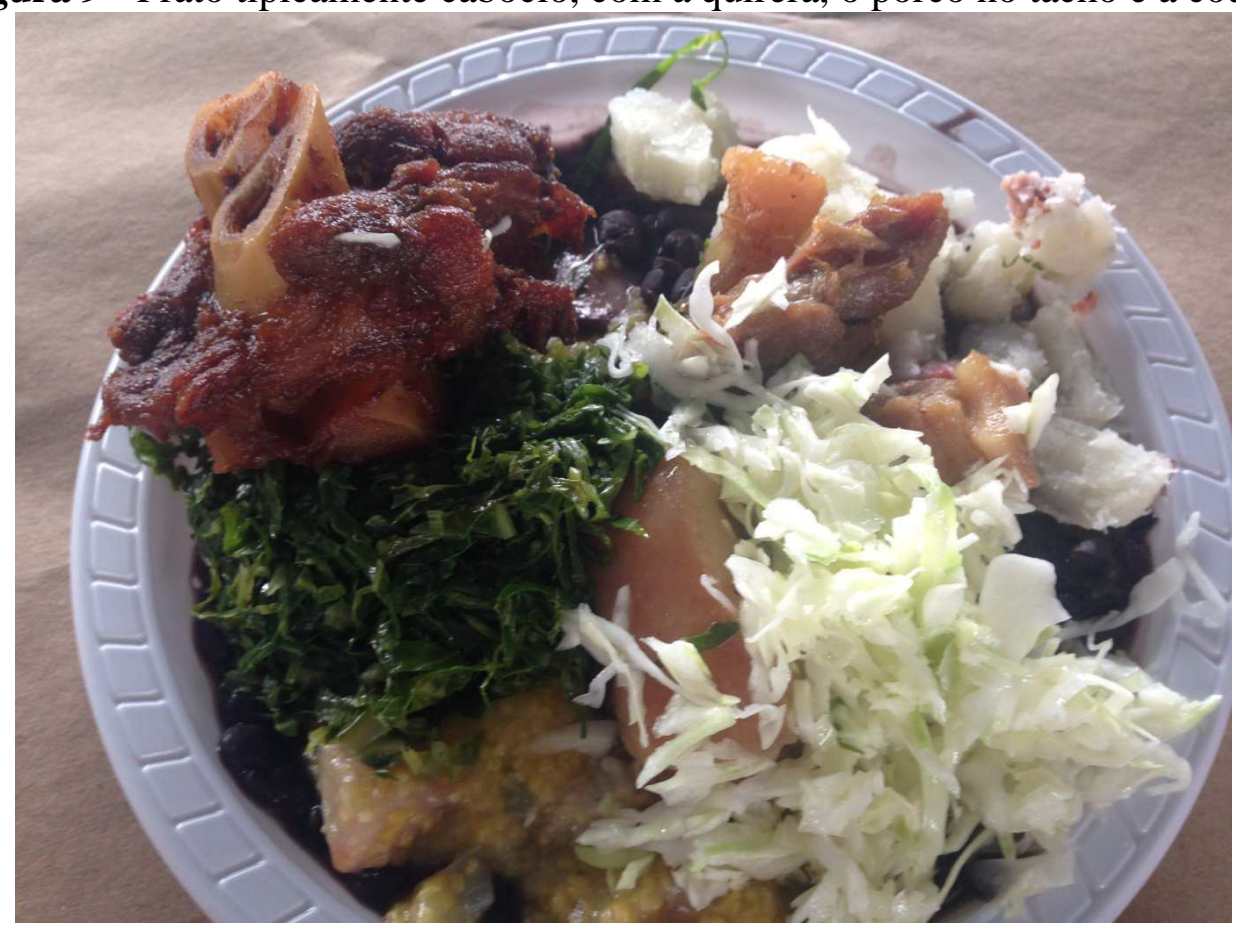

Fonte: os autores, 2015

Nosso terceiro trabalho de campo se deu em Calmon (localidade de São João de Cima), município de Santa Catarina. No dia 09 de maio de 2015, partimos em companhia de Márcia Elizabete Schüler (Márcia), João Batista Ferreira dos Santos (JB), Jayne Ferreira dos Santos (Jayne) e Alcebiades dos Anjos (Vereador Bide). A complexidade de se encontrar tais áreas, ainda com domínio de floresta de Araucária conservada, em que fosse de fácil acesso, fez com que nos dirigíssemos à propriedade de Bide, que possui uma área extensa de araucárias, que permitiu com que o campo fosse realizado, conforme a figura 10 abaixo. 
Figura 10 - Local escolhido para o campo e para a sapecada.

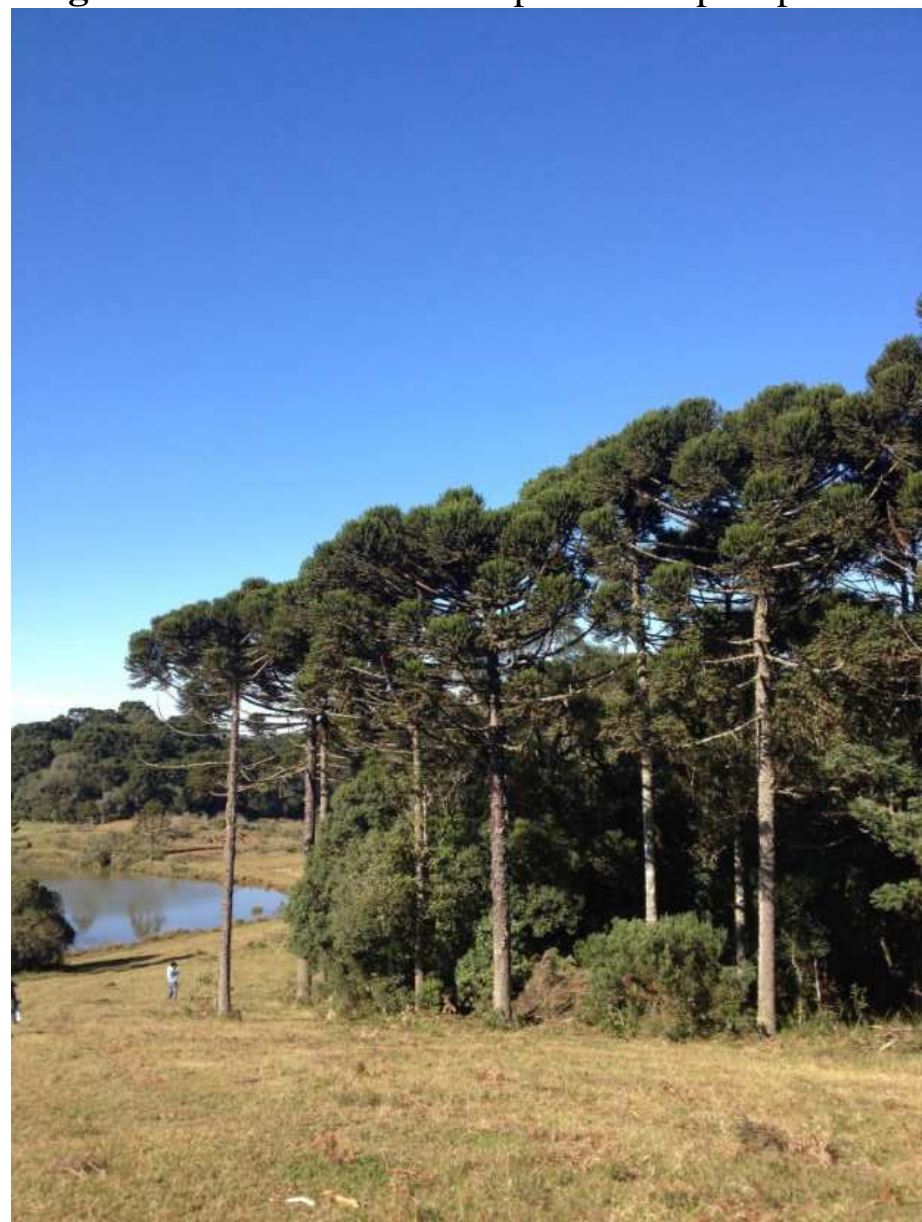

Fonte: os autores, 2015.

Não foi difícil encontrar pinhão no chão da propriedade. Com o amadurecimento da pinha, naturalmente, ocorre o desfalhamento, onde a pinha se abre fazendo com que o pinhão e as "cascas" caiam no chão, servindo de base de alimentação tanto para as pessoas como para os porcos, esses últimos, no processo de engorda, isso sem contar que é, ainda, alimento nutritivo para aves e roedores. Algumas pessoas tentam acelerar esse processo, conforme aponta Bide e JB, quebrando os galhos das araucárias e abrindo a pinha antes de seu amadurecimento, fazendo que se encontre o pinhão ainda não totalmente maduro; nisto, acabam deixando as pinhas abertas no chão, prejudicando a araucária e o seu amadurecimento normal. Bide deixa sua propriedade "aberta", permitindo que os habitantes da região façam a cata do pinhão para o seu consumo, a figura 3 nos permite ver uma pinha aberta ao pé de uma araucária. 
Figura 11 - Pinha, com pinhões em madurecimento, caída ao pé de uma araucária.

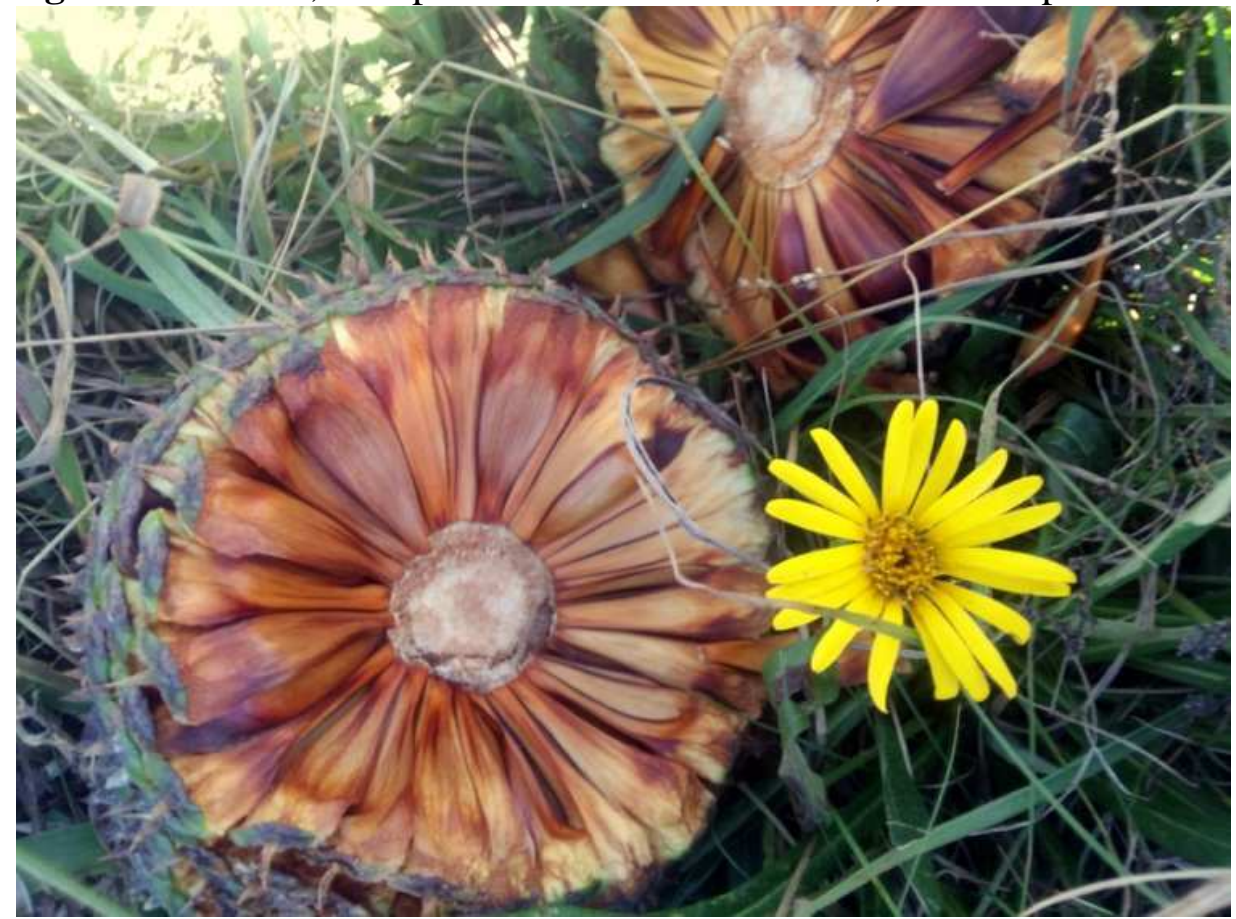

Fonte: os autores, 2015.

O primeiro passo do processo que envolve a sapecada é realizar a cata do pinhão. Embaixo de cada araucária, é possível encontrar uma porção de pinhões. Bide indica que o pinhão maduro é o que possui uma casca mais amarelada, diferentemente do pinhão com a casca mais escura, que já está a muito tempo depositada no chão. Absorvido tal aprendizado, o pinhão "catado" era colocado em um saco plástico levado por Bide; JB colocava o pinhão em seu chapéu, talvez o ato mais caboclo advindo de um típico caboclo da região. O conhecimento adquirido nessa relação com a terra é único: a noção da época de colheita e o processo de "cata" do pinhão é uma especificidade da paisagem: ela acaba sendo marcada pelos caboclos, que tem sua matriz a araucária, que em seu ciclo natural, rege os esquemas de ação e de percepção dos caboclos e, não duvidamos que esse processo ancestral, tem origem com os Xokleng e os Kaingang.

Após uma quantidade "catada", fomos até a área com maior densidade de araucárias para realizar a sapecada. Esse ato expressa primordialmente o papel da natureza e da floresta de araucária na vida dos caboclos. A araucária, além da semente comestível, concede aos caboclos a grimpa - ramos secos -, que serve de base para realização da sapecada. Após realizar uma espécie de "cama" com a grimpa, o pinhão é colocado delicadamente sob a manta de grimpa, fazendo com que ele fique encoberto por essa "cama" e que fique sobre ela também, conforme figura 4. 
Figura 12 - Pinhão sendo colocado na "cama" formada pela grimpa, advinda da Araucária.

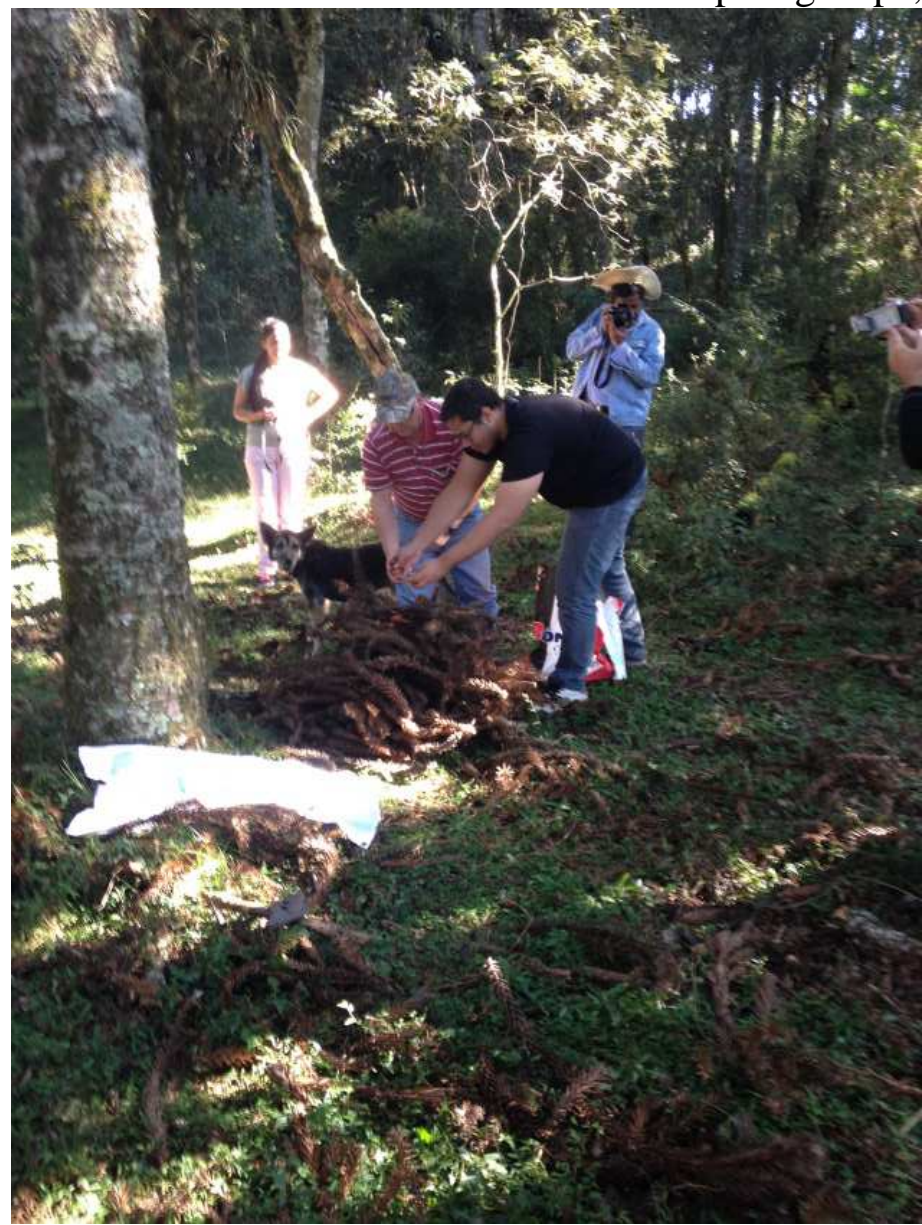

Fonte: os autores, 2015.

Após colocar todo pinhão catado na grimpa, com ajuda de um isqueiro, ateia-se fogo, fazendo com que a grimpa queime de forma rápida, pois a seiva dos seus ramos secos é altamente inflamável. Seguramente, os caboclos utilizavam-se de um isqueiro caboclo, composto de querosene. O calor emanado pelo braseiro da grimpa é intenso (figura 5); essa prática servia, também, para aquecer os caboclos em tempos gélidos, ao passo que os invernos da região são rigorosos, com geadas intensas e, ocasionalmente, precipitação de neve. O fogo se alastra pela grimpa facilmente, permitindo que o pinhão seja sapecado em tempo certo, sem que fique demasiadamente cru ou que fique completamente tostado pelo calor intenso. 
Figura 13 - A grimpa pegando fogo, sapecando o pinhão.

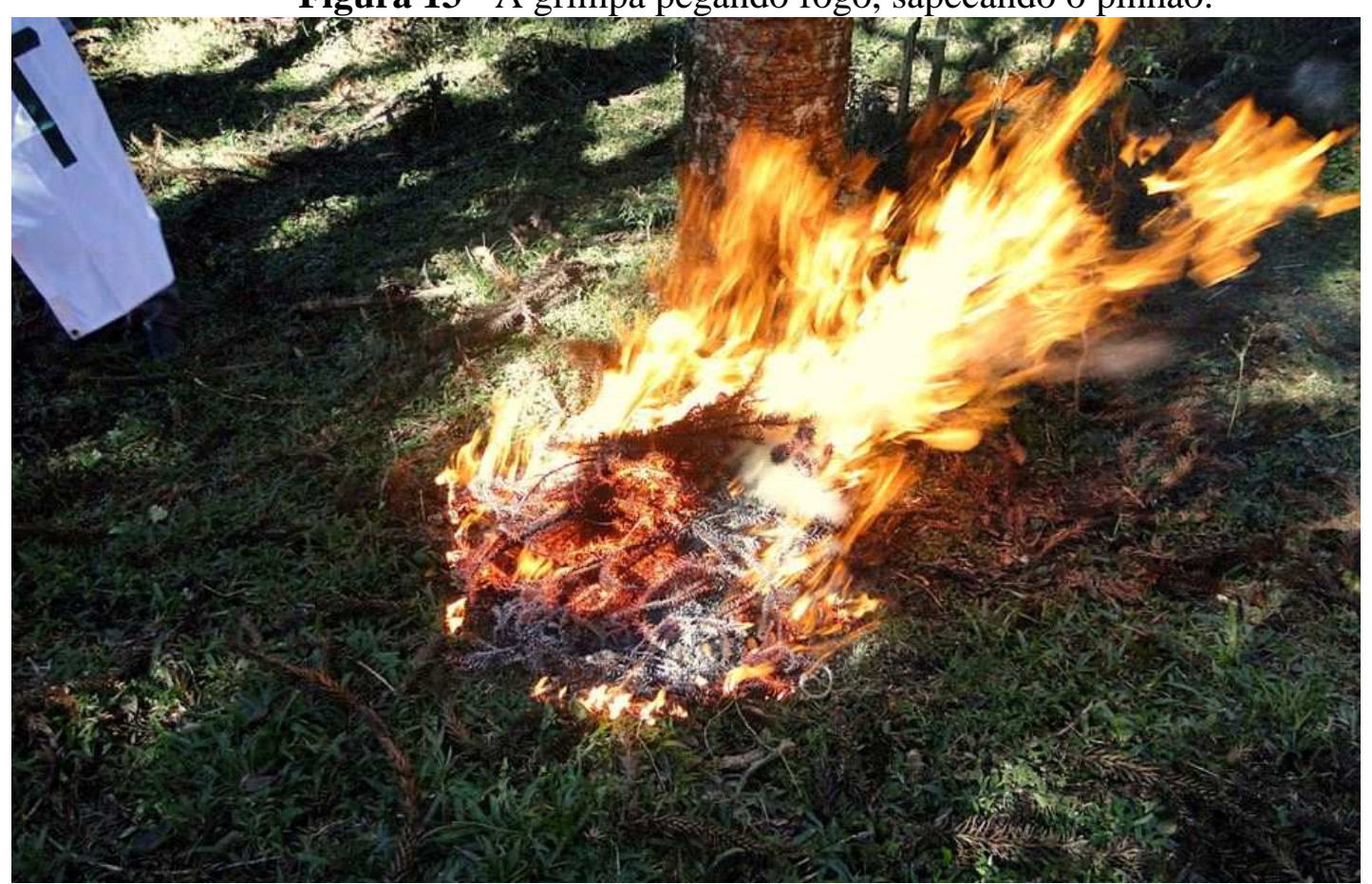

Fonte: os autores, 2015.

O fogo da grimpa se esvai naturalmente; porém, com ajuda de um ramo de folhas da vegetação das proximidades se bate no braseiro e nas cinzas para que se abafe o calor e que possíveis brasas sejam apagadas. Após este procedimento, em meio as cinzas e os galhos queimados, o pinhão sapecado aparece. Alguns tiveram suas cascas estouradas, e estão soltos em meio aos resíduos da queimada; outros ainda estão enclausurados em suas cascas, que são facilmente retirados. Alguns acabam ficando com a casca mais dura; para isso, os caboclos se utilizavam de dois pedaços de madeira retirados da própria localidade e eram amassados com a pressão exercida de um pedaço de pau sobre o pinhão sapecado, que, ao arrebentar sua casca, libera o pinhão para ser comido. A figura 6 representa o pinhão após a sapecada e, a figura 7, o pinhão retirado de sua casca, pronto para ser consumido. 
Figura 14 - O pinhão sapecado, após a grimpa ter sido apagada com um ramo de folhas

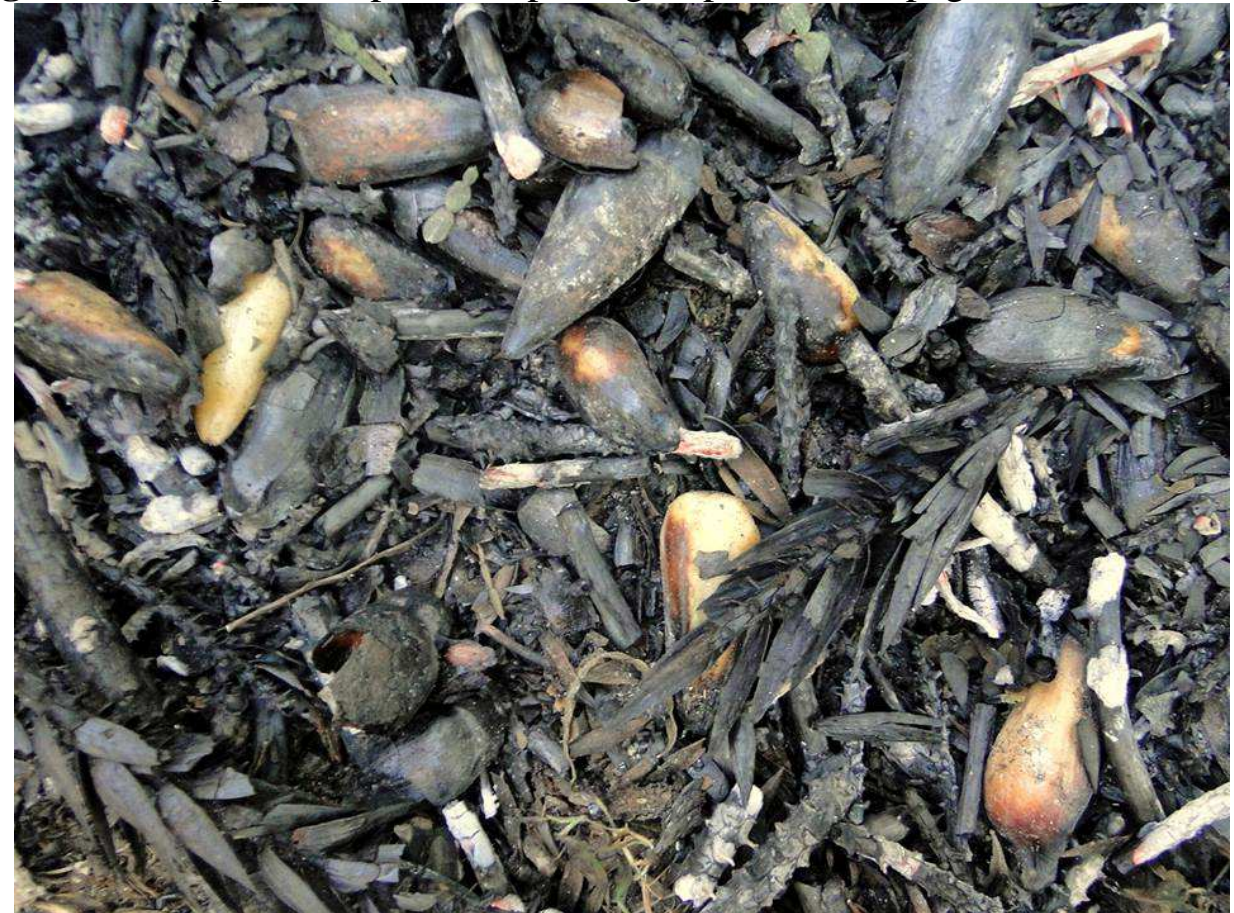

Fonte: os autores, 2015.

Figura 15 - O pinhão sapecado, pronto para ser saboreado.

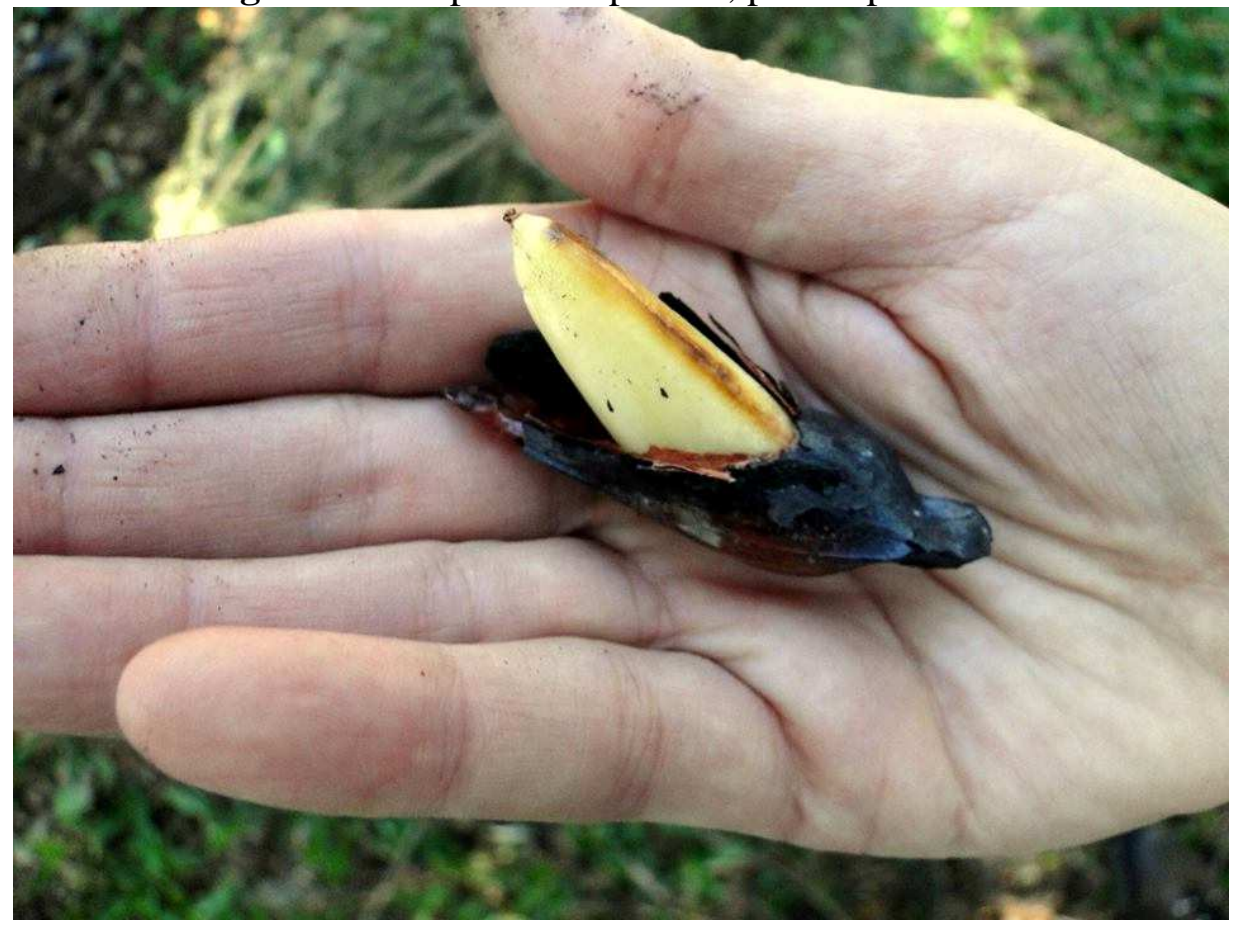

Fonte: os autores, 2015. 
Esses saberes são únicos. A floresta de araucária provê, ainda, o pinhão e a grimpa, permitindo que esta atividade seja realizada. Ela é uma das variadas formas de se preparar o pinhão, que é consumido, ainda, cozido na panela com água ou assado sobre a chapa de um fogão a lenha; ela faz parte de uma prática secular da região que ainda não se perdeu, principalmente por ser uma das formas de preparo do pinhão que lhe concede um sabor único e tipicamente caboclo, como afirmam JB, Bide e Márcia. Quando se prova essas três formas mencionadas de preparo do pinhão, se chega a conclusão de que o pinhão sapecado na grimpa é o que mais nos aproxima da alma identitária cabocla do Contestado, pois há uma mistura entre o sabor do pinhão com a seiva e a fuligem da sapecada, dotando ele, de um gosto impregnado de significados, com cheiro e paladar que remetem a tempos ancestrais daquela porção territorial do Sul do Brasil. Bataburu (2012a) revela essa prática, ao indicar que quando não se leva paçoca de pinhão para as matas, "come-se o próprio pinhão colhido, muitas vezes até cru. O habitual, porém, é assá-lo nos galhos secos do pinheiro (as 'grimpas') naquilo que é conhecido como 'sapecada'" (BATABURU, 2012a). A floresta de araucária é a matriz da paisagem: ela rege as formas de percepção e ação dos caboclos, provendo o alimento e as condições de se preparar os alimentos; o caboclo é a marca, por marcar ela nos atos de cata e de próprio preparo do pinhão - sendo um inseparável conjunto.

Todavia, é importante destacar o papel do agronegócio e do capital agressivo que adentra a região: a floresta está se perdendo, ou melhor, sendo eliminada. São apenas alguns fragmentos na região em que se é possível encontrar uma área de araucárias. Esse problema se estende desde as épocas pré-guerra e pós-guerra do Contestado, onde a atuação de madeireiras como a Lumber, edificada pela Brazil Railway Company perpetuou a extração da Araucária, situando-se em Três Barras e Calmon, municípios catarinenses (FRAGA, 2010). Bataburu (2012b) indica esse mesmo quadro, onde "cerca de 100 milhões de pinheiros nativos viraram toras nas serrarias do Sul e do Sudeste. Dos 185 mil quilômetros quadrados de floresta de araucária (Araucaria angustifolia) que antes cobriam nossas serras meridionais, restaram apenas 2\%" (BATABURU, 2012b).

Sabor, paisagem, imaginário, hedonismo e cultura. Estes elementos são constituidores do conhecimento caboclo e do sabor do pinhão sapecado. Fomos provocados após a sapecada e os trabalhos de campo: "Quero ver descreveres este sabor!". Sabor de caboclo, sabor de guerra, sabor de(do) Contestado, preparado em solo ainda eivado de sangue, dor, e sofrimento. O sabor é impróprio de ser descrito: seria um afronta aos caboclos que se utilizaram dessa prática para subsistência (ou autoconsumo) e para sobreviver em meio aos gélidos planaltos rasgados pela dor 
de uma Guerra infindável, que ainda possui raízes na região, perpetuando a miséria e o subdesenvolvimento, cuja fome, quando há araucárias e pinhões, é saciada nas seculares sapecadas.

\section{CONCLUSÕES}

A fissura causada na geografia pelos geógrafos humanistas ao propor um estudo geográfico dos sabores é fundamental para se pensar numa geografia realmente humanista que, de fato, incorpore as questões relativas à experiência geográfica, não subjugando os demais sentidos e tomando-os como dimensões fundamentais da experiência geográfica. O próprio Yi-Fu Tuan (2011) fez menção ao paladar, ao indicar que estes em conjunto com o tato e o olfato dariam qualidade ao espaço, enquanto a visão e a audição seriam os sentidos espacializadores por excelência. Logo, pensar o sabor é colocar o paladar em evidência, pensando a percepção não unicamente pela via da visão e da audição mas, também, pelos demais sentidos corpóreos, que mediam a relação do ser cognoscente com o mundo, como indicara Merleau-Ponty (2013).

Pensar o sabor é pensar, em conjunto os saberes e da paisagem, sendo uma espécie de resgate das premissas clássicas da geografia cultural, incorporando-as ao debate da existência e da experiência humana dos espaços, lugares e paisagens. A paisagem passa a se tornar a essência geográfica fundamental para se pensar o sabor na geografia, por ser a essência geográfica antepredicativa, outorgando os lugares e a nossa relação com os lugares, ao passo que paisagens insossas e desagradáveis podem engendrar sentimentos de repulsão e desafeto ao lugar (topofobia), bem como paisagens coloridas e saborosas podem engendrar sentimentos de afetividade e de relação com o lugar (topofilia), dando base para o pensamento geográfico humanista, e paisagens mortas e desaparecidas podem causar a morte do lugar (topocídio).

O conceito de paisagem proposto para a pesquisa se mostrou de alto valor teóricometodológico para se pensar os sabores pela via da identidade regional. A paisagem é marcada pelos homens, mas também rege os modos de percepção do homem, de vida e de ação, como propôs Augustin Berque (2012). A paisagem foi e é marcada pelos caboclos, e a partir dela que eles ainda retiram sua sobrevivência, seja com a criação de porcos soltos que servirão de base para a quirera com porco, seja na produção do milho que servirá de base para o fubá, a canjica e a própria quirera, 
bem como a existência de ervais na região, processados e moídos para se tomar o chimarrão, e as araucárias, que concedem ao caboclo um dos símbolos da região sul brasileira, o pinhão, que ainda é largamente consumido na região de estudo.

Ainda, conforme indicaria Holzer (2012), o estudo do sabor pode perseguir, também, a conservação ambiental, ao passo que o ainda aproveitamento dos produtos da natureza para a subsistência causa uma resistência ao avanço em determinados lugares do capital e da apropriação capitalista do espaço agrário, o que causa graves problemas ambientais. Como observado no terceiro trabalho de campo, na propriedade do senhor Alcebiades dos Anjos, há áreas importantes de fragmentos de mata de araucária preservadas, pois de lá retira o pinhão tanto para seu consumo como para o consumo das pessoas da região. Carecem ainda estudos da contribuição efetiva dos sabores na preservação e conservação ambiental, todavia, ele adquire um papel importante neste quesito.

Os sabores estudados durante a pesquisa refletem a cultura cabocla. Essa cultura alimentar apresenta-se como um "suspiro" de identidade e de cultura que restou dos tempos da guerra, onde havia uma tentativa extrema de obliteração tanto da existência dos caboclos como da cultura cabocla. Esse processo é o que Haesbaert (2003) aponta como o de desterritorialização extrema, ou seja, a perda tanto da terra e do solo como da cultura e da identidade, fazendo com que um povo ou uma cultura seja totalmente obliterada e destruída. Os processos atuais de globalização e do desenvolvimento desenfreado do capitalismo, esses procedimentos de preparo podem se perder, não totalmente, mas parcialmente, ao passo que estes processos ainda são vistos em áreas rurais mais afastadas da cidade. Holzer $(2012 ; 2014)$ apontou esse mesmo processo ao estudar a culinária e os pratos caiçaras no litoral do Rio de Janeiro, onde a turistificação da região estaria causando a perca da identidade e da culinária local.

Logo, o estudo do sabor é fundamental tanto para a preservação e conservação ambiental, para a preservação de culturas alimentares seculares, sem se perderem para a industrialização intensa da alimentação e o aumento propalado de redes de fast-food, e para o estudo mais profícuo e fundamental da existência humana e da experiência geográfica. 


\section{REFERÊNCIAS}

AB'SABER, Aziz Nacib. Os domínios de natureza no Brasil: potencialidades paisagísticas. São Paulo: Ateliê, 2003. 151 p.

BARTABURU, Xavier. Pinhão no prato, pinheiro de pé. 2012b. Disponível em: <http://viajeaqui.abril.com.br/materias/pinhao-no-prato-pinheiro-no-pe>. Acesso em: 14 jun. 2015.

BARTABURU, Xavier. Pinhão: paçoca, entrevero e sapecada. 2012a. Disponível em: <http://viajeaqui.abril.com.br/materias/pinhao-pacoca-entrevero-e-sapecada>. Acesso em: 14 jun. 2015.

BERQUE, Augustin. Paisagem-marca, paisagem-matriz: elementos da problemática para a geografia cultural. In: ROSENDAHL, Zeny; CORRÊA, Roberto Lobato. (Org.). Geografia Cultural: uma antologia (1). Rio de Janeiro: EdUERJ, 2012. p. 239-244.

BESSE, Jean-Marc. Anexo: Geografia e Existência a partir da obra de Eric Dardel. In: DARDEL, Eric. O Homem e a Terra: natureza da realidade geográfica. (Trad. Werther Holzer). São Paulo: Perspectiva, 2011. p. 111-139.

BESSE, Jean-Marc. Ver a Terra: seis ensaios sobre a paisagem e a geografia. (Trad. Vladimir Bartalinii). São Paulo: Perspectiva, 2006. 108 p.

BOTELHO, Adriano. Geografia dos Sabores: ensaio sobre a dinâmica da cozinha brasileira. Textos do Brasil, n. 13. Disponível em: <http://dc.itamaraty.gov.br/imagens-e-textos/revista-textos-dobrasil/portugues/revista13-mat10.pdf>. Acesso em: 16 jun. 2015.

CLAVAL, Paul. A Geografia Cultural. Florianópolis: Ed. UFSC, 1999. 453 p.

COSTA, Samuel Guimarães da. A erva-mate. Curitiba: Coleção Farol do Saber, 1995.

DARDEL, Eric. O Homem e a Terra: natureza da realidade geográfica. Tradução Werther Holzer. São Paulo: Perspectiva, 2011. 108 p.

FRAGA, Nilson Cesar. Araucaria angustifolia - ganância, imediatismo e extermínio na região do Contestado. In: (Org.). Contestado: o território silenciado. Florianópolis: Insular, 2009. p. 257-283.

FRAGA, Nilson Cesar; LUDKA, Vanessa Maria. 100 anos da Guerra do Contestado, a maior guerra camponesa na América do Sul (1912/2012): uma análise dos efeitos sobre o território sulbrasileiro. In: COLOQUIO INTERNACIONAL DE GEOCRITICA, 12., 2012, Bogotá. Anais... Bogotá: Universidad Nacional de Colômbia, 2012. p. 1-10.

GOMES, Paulo Cesar da Costa. Geografia e Modernidade. 3. ed. Rio de Janeiro: Bertrand Brasil, 2003. 
GOMES, Paulo Cesar da Costa; RIBEIRO, Letícia Parente. Cozinha geográfica: a propósito da transformação de natureza em cultura. Espaço e Cultura, Rio de Janeiro, n. 29, p. 69-81, jan./jun. 2011.

GRATÃO, Lúcia Helena Batista; MARANDOLA JR., Eduardo. Sabor da, na e para Geografia. Geosul, Florianópolis, v. 26, n. 51, p. 59-74, jan./jun. 2011.

HAESBAERT, Rogério. Desterritorialização: entre as redes e os aglomerados de exclusão. In: CASTRO, Iná Elias de; GOMES, Paulo Cesar da Costa; CORRÊA, Roberto Lobato. (Org.). Geografia: conceitos e temas. 4. ed. Rio de Janeiro: Bertrand Brasil, 2002. p. 165-206.

HOEFLE, Scott William. Epistemologia e teoria cultural. In CORRÊA, Roberto Lobato; ROSENDAHL, Zeny. Geografia cultural: uma antologia (1). Rio de Janeiro: EDUERJ, 2012.

HOLZER, Werther. Cozinhas e comida caseira: pratos com peixe e paisagens de resting. Geograficidade, Niterói, v. 2, n. 1, 2012.

HOLZER, Werther. O sabor do sal: paisagens vernaculares de Araruama. Geograficidade, Niterói, v. 4, número especial, p. 47-58, outono 2014.

LINHARES, Temístocles. História econômica do mate. Rio de Janeiro: José Olympio, 1969.

MACIEL, Maria Eunice. Uma cozinha à brasileira. Estudos Históricos, Rio de Janeiro, n. 33, p. 25-39, jan./jun. 2004.

MARANDOLA JR., Eduardo. Da existência e da experiência: origens de um pensar e de um fazer. Cadernos de Geografia, Belo Horizonte, v. 15, n. 24, p. 49-67, 1º sem. 2005.

MARANDOLA JR., Eduardo. Geosofia e Humanismo - do conhecimento geográfico à Geografia do Conhecimento. In: KATUTA, Ângela Massumi; SILVA, William Ribeiro. (Org.). O Brasil frente aos arranjos espaciais do Século XXI. Londrina: Humanidades, 2007. p. 269-298.

MARANDOLA JR., Eduardo. Saberes de corpos alimentados: ensaio de geografia hedonista. Geograficidade, Niterói, v. 4, número especial, p. 16-24, outono 2014.

MARANDOLA JR., Eduardo. Sabor enquanto experiência geográfica: por uma geografia hedonista. Geograficidade, Niterói, v. 2, n. 1, p. 42-52, verão 2012.

McDOWELL, Linda. As transformações da geografia cultural. In: GREGORY, Derek; MARTIN, Ron; SMITH, Graham. (Org.). Geografia Humana: sociedade, espaço e ciência social. Rio de Janeiro: Jorge Zahar Editor, 1996. p. 159-188.

MELLO, João Baptista Ferreira de. Geografia Humanística: a perspectiva da experiência vivida e uma crítica radical ao positivismo. Revista brasileira de Geografia, Rio de Janeiro, v. 52, n. 4, p. 91-116, 1990.

MERLEAU-PONTY, Maurice. Fenomenologia da Percepção. (Trad. Carlos Alberto Ribeiro de Moura). 4. ed. São Paulo: Editora WMF Martins Fontes, 2011. 662 p. 
PALHARES, Virgínia de Lima. Uma geografia hedonista dos saberes e dos sabores. Geograficidade, Niterói, v. 4, número especial, p. 25-35, outono 2014.

QUEIROZ, Maurício Vinhas de. Messianismo e Conflito Social: a Guerra sertaneja do Contestado (1912-1916). 3. ed. São Paulo: Ática, 1981. 323 p.

RELPH, Edward. Reflexões sobre a emergência, aspectos e essência de lugar. In: MARANDOLA JR., Eduardo; HOLZER, Werther; OLIVEIRA, Lívia de. (Org.). Qual o Espaço do Lugar?: Geografia, epistemologia, fenomenologia. São Paulo: Perspectiva, 2012. p. 17-32.

SANTOS, Carlos Roberto Antunes dos. A alimentação e seu lugar na história: os tempos da memória gustativa. História: Questões \& Debates, Curitiba, n. 42, p. 11-31, 2005.

SANTOS, Carlos Roberto Antunes dos. Apresentação. In: MENEZES, Helena. Pinhão indígena a culinária do Paraná. Curitiba: SENAC, 2008. p. 10-14.

SANTOS, Carlos Roberto Antunes dos. História da Alimentação no Paraná. Curitiba: Fundação Cultural, 1995.

SAUER, Carl. Geografia Cultural. Espaço e Cultura, Rio de Janeiro, n. 3, p. 1-7, jan. 1997.

SERRES, Michel. Narrativas do Humanismo. Tradução Caio Meira. Rio de Janeiro: Bertrand Brasil, 2015. 301 p.

SILVEIRA, Heitor Matos da; FRAGA, Nilson Cesar. Reverberações do sabor na Geografia: cultura, hedonismo, imaginário - notas reflexivas a partir de um marco teórico. In: SEMANA DE GEOGRAFIA DA UEL, 31., 2015, Londrina. Anais... Londrina: GEOTMAC, 2015. p. 900-912.

SOKOLOWSKI, Roberto. Introdução à Fenomenologia. 3. ed. São Paulo: Edições Loyola, 2012. 247 p.

TUAN, Yi-Fu. Topofilia: um estudo da percepção, atitudes e valores do meio ambiente. (Trad. Lívia de Oliveira). Londrina: Eduel, 2012.

WAGNER, Philip L.; MIKESELL, Marvin W. Os temas da Geografia Cultural. In: CORRÊA, Roberto Lobato; ROSENDAHL, Zeny. (Org.). Introdução à Geografia Cultural. Rio de Janeiro: Bertrand Brasil, 2003. p. 27-62.

WRIGHT, John K. Terrae incognitae: o lugar da imaginação na Geografia. Geograficidade, v. 4, n. 2, p. 4-18, inverno 2014.

WRIGHT, John K. Terrae incognitae: the place of imagination in Geography. Annals of the Association of American Geographers, v. 37, n. 1, p. 1-15, mar. 1947. 


\title{
FIRE (IN) GROUND FLOOR: PINHÃO, QUIRERA AND CHIMARRÃO - FOOD AS CULTURAL BASE CONSTESTADO'S REGION
}

\begin{abstract}
The present paper have as scope to appoint the results obtained during the research "Flame of (in) the ground: pinhão, quirera and chimarrão - food as cultural basis of Contestado's Region" where we discussed the concept of savor in Geography from the typical foods of the referred region and the caboclo, such as quirera com porco, the pinhão sapecado and the consumption of erva-mate. Geography took a long time to stablish relations with the study of alimentation, differently of what happened with, Anthropology that has in its founding basis the study of alimentation practices and History, in its studies of the history of alimentation. Although the late relation, cultural geographers started to considerate the alimentation and the process of cooking as cultural acts, aiming to comprehend since the production to the ways of consumption, cooking and prepare. With the ascension of humanist geography and the seek of a organic geography and science, caring about the geographical experience, mediate by the body senses. Savor, knowledge and landscape are the main triad of this study, by the time that the knowledge of prepare, cook and harvest of aliments creates specific landscapes of each place, coordinating the savor of places and regions. The pinhão, the quirera with pork and the chimarrão are de alimentary basis of the caboclo and create landscapes from those savors, requiring a deeper study to think in culture, identity and environment.
\end{abstract}

Keywords: Cultural-Humanist Geography. Savor. Contestado's Region. 